\title{
Palmar-plantar erythrodysesthesia
}

\author{
Arjun Gupta, ${ }^{1}$ Anurag Mehta, ${ }^{1}$ Sahil Khanna ${ }^{2}$
}

${ }^{1}$ University of Texas

Southwestern Medical Center, Dallas, Texas, USA

${ }^{2}$ Division of Gastroenterology and Hepatology, Mayo Clinic, Rochester, Minnesota, USA

\section{Correspondence to}

Dr Sahil Khanna,

khanna.sahil@mayo.edu

Accepted 23 August 2015

\section{DESCRIPTION}

A 59-year-old woman presented with pain, tingling and desquamation over bilateral palms and soles for 4 weeks, associated with inability to perform activities of daily living (ADL). She had received 5-fluorouracil, bevacizumab and irinotecan for metastatic colon cancer 6 weeks earlier. Examination revealed diffuse hyperpigmentation

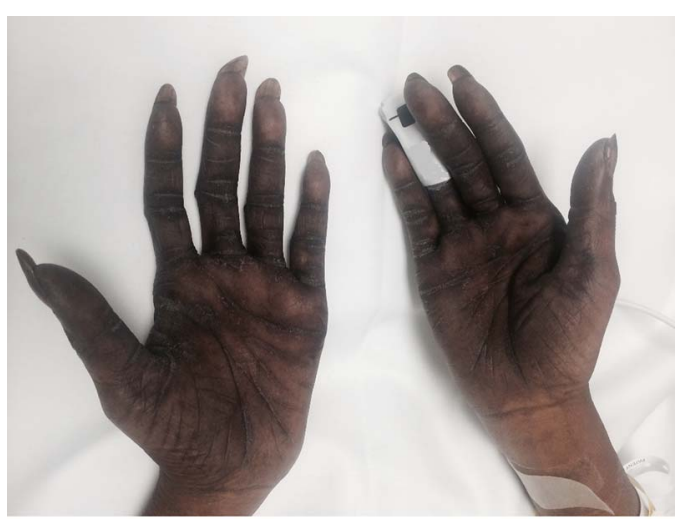

Figure 1 Volar aspect of bilateral palms demonstrating diffuse hyperpigmentation and skin peeling, and skin atrophy of the distal fingernails. The patient experienced pain and had difficulty performing activities of daily living.

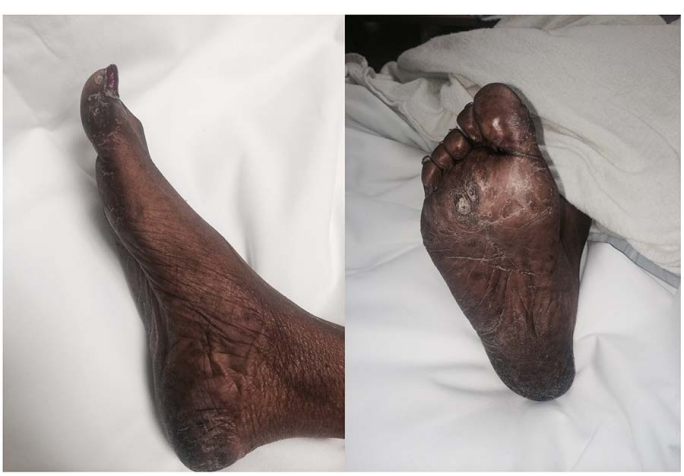

Figure 2 Medial and volar aspect of the right foot demonstrating dry desquamation, skin peeling, blistering and a $1 \mathrm{~cm} \times 1 \mathrm{~cm}$ ulceration. and blisters on palms and soles, and an ulcer over the right plantar surface (figures 1 and 2). A clinical diagnosis of grade 3 palmar-plantar erythrodysesthesia (PPE) was made, and she was treated with topical emollients. Chemotherapy was held and she ultimately opted for hospice care.

This report is targeted for general practitioners, internists and emergency room physicians who may not encounter PPE often. PPE, or chemotherapyassociated acral erythema, is a cutaneous toxicity syndrome traditionally associated with cytotoxic chemotherapy agents (5-fluorouracil, docetaxel, cytarabine, liposomal doxorubicin, capecitabine); however, it is increasingly being associated with use of molecular agents (sorafenib, sunitinib, axitinib, pazopanib). Incidence, which was traditionally in the $10 \%$ range, has shot up and may be as high as $62 \%$ in patients treated with sorafenib. ${ }^{1}$ Symptoms include dysesthesia and tingling, progressing to pain and swelling, blistering, desquamation and ulceration. Severity is graded per the Common Terminology Criteria for Adverse Events (CTCAE) $\mathrm{V} .4$, with grade 3 reflecting severe skin changes and difficulty performing self-care ADL (table 1). ${ }^{2}$ The pathogenesis is incompletely understood, but direct chemotherapy toxicity due to leakage into the capillary bed is a potential mechanism. Higher cumulative dose and sustained serum levels of cytotoxic drugs are more frequently associated with PPE occurrence. ${ }^{3}$ Differential diagnoses include erythromelalgia, graft-versus-host disease and Raynaud's disease. Patients with grade 1 PPE are managed symptomatically and severe PPE (grade 2 or 3) needs dose reduction in chemotherapy or a switch to an alternative regimen (if available) to avoid recurrence. Preventive strategies include avoiding contact of hands and feet with heat (sunburn and saunas) and chemicals (household cleaning), and reducing frictional contact (occupational or recreational). Vigilance and reporting early symptoms may halt progression of the condition. There are no proven therapeutic treatments but emollients (urea), moisturisers, ice packs and cooling therapy, vitamin B6 supplementation and pain relief with non-steroidal anti-inflammatory drugs may provide symptomatic relief.
To cite: Gupta A, Mehta A, Khanna S. BMJ Case Rep Published online: [please include Day Month Year] doi:10.1136/bcr-2015212434
Table 1 CTCAE V.4, guidelines reflecting the severity of palmar- plantar erythrodysesthesia ${ }^{2 *}$

\begin{tabular}{|c|c|c|c|c|}
\hline Adverse event & Grade 0 & Grade 1 & Grade 2 & Grade 3 \\
\hline $\begin{array}{l}\text { Palmar-plantar } \\
\text { erythrodysesthesia } \\
\text { syndrome }\end{array}$ & $\begin{array}{l}\text { No } \\
\text { symptoms }\end{array}$ & $\begin{array}{l}\text { Minimal skin changes or } \\
\text { dermatitis (eg, erythema, } \\
\text { oedema, or hyperkeratosis) } \\
\text { without pain }\end{array}$ & $\begin{array}{l}\text { Skin changes (eg, peeling, } \\
\text { blisters, bleeding, oedema, or } \\
\text { hyperkeratosis) with pain; } \\
\text { limiting instrumental ADL }\end{array}$ & $\begin{array}{l}\text { Severe skin changes (eg, peeling, } \\
\text { blisters, bleeding, oedema, or } \\
\text { hyperkeratosis) with pain; } \\
\text { limiting self-care ADL }\end{array}$ \\
\hline
\end{tabular}




\section{Learning points}

- Palmar-plantar erythrodysesthesia is a debilitating complication of some commonly used chemotherapeutic agents.

- Patients with grade 2 or 3 palmar-plantar erythrodysesthesia require dose reduction or an alternative chemotherapy regimen to avoid recurrence.

\section{REFERENCES}

1 Lipworth AD, Robert C, Zhu AX. Hand-foot syndrome (hand-foot skin reaction, palmar-plantar erythrodysesthesia): focus on sorafenib and sunitinib. Oncology 2009;77:257-71.

2 http://evs.nci.nih.gov/ftp1/CTCAE/CTCAE_4.03_2010-06-14_QuickReference_8.5×11. pdf

3 Webster-Gandy JD, How C, Harrold K. Palmar-plantar erythrodysesthesia (PPE): a literature review with commentary on experience in a cancer centre. Eur J Oncol Nurs 2007;11:238-46.

Competing interests None declared.

Patient consent Obtained.

Provenance and peer review Not commissioned; externally peer reviewed.

Copyright 2015 BMJ Publishing Group. All rights reserved. For permission to reuse any of this content visit http://group.bmj.com/group/rights-licensing/permissions.

BMJ Case Report Fellows may re-use this article for personal use and teaching without any further permission.

Become a Fellow of BMJ Case Reports today and you can:

- Submit as many cases as you like

- Enjoy fast sympathetic peer review and rapid publication of accepted articles

- Access all the published articles

- Re-use any of the published material for personal use and teaching without further permission

For information on Institutional Fellowships contact consortiasales@bmjgroup.com

Visit casereports.bmj.com for more articles like this and to become a Fellow 